\title{
Women on the Acropolis and Mental Mapping: Comic Body-Politics in a City in Crisis, or Ritual and Metaphor in Aristophanes' Lysistrata
}

\author{
Anton Bierl*
}

\section{Introduction}

Lysistrata represents a real 'crisis on stage'. The play was produced in 411 $\mathrm{BCE}$, probably at the Lenaia festival. We are in the middle of the Peloponnesian War, already twenty years after the outbreak of the devastating struggle between Athens and Sparta. Both cities had emerged as the dominant Greek powers from the Persian Wars (490-478 BCE) - a period seen as a utopian Golden Age in Attic comedy. After the first phase, the Sicilian disaster turned the tide of the Peloponnesian War against the Athenians in 413 BCE: the great Athenian armada was heavily defeated in Sicily having set sail in 415 BCE in the hope of conquering the island. Several major allies immediately defected from Athens to the Spartan Alliance. By the end of 412 BCE, however, the Athenians managed to stave off the threat of total defeat by winning back some strategic outposts and rebuilding their navy. This went hand in hand with the further concentration of political power: the autonomy of the assembly was severely curtailed. In particular, an extraordinary board of elder and experienced statesmen, among them the aged Sophocles, was appointed to manage the affairs of the state. The so-called probouloi could expedite war efforts by bypassing the Council. In Lysistrata (387-613, esp. 551-613) a proboulos is fiercely ridiculed onstage; he is

* I would like to thank Antonios Rengakos for his kind invitation to Thessaloniki, as well as the editors of this volume, Andreas Markantonatos and Bernhard Zimmermann. I have been thinking on the topic of this article for more than a decade, as I already announced it in Bierl 2001, 233 n. 352. It should be noted that this article complements Bierl 2007b (= Engl. [forthcoming]). Burkert 1966 (see now Bierl 2010, esp. 27) and Loraux 1981, 157-196 (Engl. 1993, 147-183) have been my main inspirations for this paper. 
dressed as a woman and decked out as a corpse being prepared for the last rites.

In 411 BCE Athens' situation was still parlous. Officers of the Athenian naval base at Samos had secretly begun negotiations with the exiled Alcibiades, who had promised to bring Persia over to Athens' side, if the Athenians recalled him and introduced a more moderate constitution. General Peisandrus, the only politician mentioned in Lysistrata by name, had recently returned from Samos to negotiate Alcibiades' conditions, but he had not yet put them before the ekklessia. In the months following the production of the play, an antidemocratic conspiracy created an atmosphere of intimidation and terror. Although these forces failed to bring back Alcibiades, they installed an oligarchic regime in the summer of 411 BCE. ${ }^{1}$

Like many other Aristophanic comedies, Lysistrata advocates the abolition of war and the establishment of a utopian peace. In order to reach this goal, the heroine comes up with the comic idea of initiating two plans: The women should (a) start a Panhellenic conjugal sex strike; and (b) occupy the Acropolis, where the League's treasury is held, in order to force the men to give up their hostilities and to return home to their families. Lysistrata is typical of Aristophanes' heroic plays, such as Acharnians, Peace, Birds, and Assembly Women. By means of a comic idea, the hero, who normally comes from a class of citizens frustrated by some negative development in society, and in particular war, succeeds in turning the initial bad situation into a good one. The hero fantastically triumphs over reality with all kinds of supernatural and magical capabilities. Only at the very end will normality be restored. For the reader's orientation I give a brief summary of the play:

1-253: Prologue: Lysistrata tells Kalonike that she has summoned the women of several Greek cities to propose a plan for stopping the war. When they come, she suggests a Panhellenic conjugal strike (plan A). With Lampito's support she persuades them to follow. They take the oath on a cup of wine. The old women have seized the Acropolis (plan B). The rest return home or go in to help.

Plan B: Occupation of the Citadel

254-386: Parodos: The half-Chorus of old men comes with faggots to burn the women out of the Acropolis. They light a fire. The half-Chorus of women brings buckets of water and makes the men wet.

387-475: Episode: A proboulos with policemen armed with crowbars is about to attack the gates, when Lysistrata and three old women come

1 See Henderson 1996, 33 f.; 2000, 254-256. 
out. The women from inside rush out and fight putting the policemen to flight.

476-613: Agōn: The proboulos questions Lysistrata, who states the women's grievances. He does not want to listen. Therefore, at the end, the women offer him female and burial ornaments. He is forced to show himself so decked to his male colleagues.

614-705: Parabasis (here as choral debate): Both semi-Choruses lay aside their cloaks and threaten each other. They dispute whether women should take part in politics. The men are not ready to follow the argumentation of the women and are finally silenced.

Plan A: Sex Strike

706-780: Episode: Lysistrata announces that some women are deserting the citadel. Several women make excuses to go home. Lysistrata produces an oracle of victory and persuades them to reenter the Acropolis.

781-828: Chorikon: Both half-Choruses defend their case by telling satirical anecdotes at the expense of women (the men mention Melanion, the misogynist) and men (the women mention Timon, the misanthrope).

829-953: Episode: Myrrhine demonstrates the female sex strike by frustrating and deluding her husband Kinesias.

954-979: Amoibaion: Kinesias laments, and the male Chorus-leader tries to console him.

980-1013: Episode: A herald from Sparta describes the distress of the men there. He and Kinesias agree to get peace legates appointed.

Reconciliation

1014-1042: Both half-Choruses settle their quarrel and assume their garments.

1043-1071: Chorikon: The Chorus, now united, condemns the war and sets out for peace. The men offer money, the women food, to the spectators.

1072-1188: Episode: The Spartan and the Athenian legates meet to discuss peace. Lysistrata produces the female personification of Diallage $\bar{e}$ and brings them to terms by reminding them of their common rituals and history. She invites them to feast in the Acropolis and afterwards to take their partners and go home.

1189-1215: Chorikon: The men and women renew their offers (feast inside).

1216-1321: The Athenian legates come out after the feast in a komos with torches. The Spartans follow with a flute-player and perform a dance praising their new unity, their common solidarity with the Athenians against the Persians. Lysistrata bids the men and women to pair off with one another. The Athenians praise their gods in a choral dance singing to Artemis, Dionysus, Zeus, Hera and Aphrodite, who has reconciled them. The Spartans respond with a dancing song providing a local Spartan setting of rituals of initiation and marriage. With a solemn hymn to Athena Chalkioikos, the Spartan equivalent to Athena Polias, all lead out their way from the orchestra. 
In Lysistrata we have a significant innovation: for the first time, the protagonist is a woman. This fact makes the play particularly interesting for questions of gender in Athenian society. However, we should not make the mistake of seeing the play as expressing a proto-feminist stance. It is well known that the role of women in Athenian society was heavily restricted: a woman was neither a citizen, who could take part in the democratic process, nor can she move freely in public, and her life was constrained chiefly to the realm of the house and family. ${ }^{2}$ It is even quite controversial whether women could visit the productions in the theatre of Dionysus. ${ }^{3}$ Women in power, as they are staged in our play, are something abnormal and exceptional, with only some ritual or mythical parallels. Gynaecocracy, in other words, is the antimodel to normality, the 'Other' that men fear in real life.

The only way a woman could play a role in Athenian society is in cultic activity. This is the reason why cult, ritual, and myth are so important for understanding this comedy in particular. ${ }^{4}$ Lysistrata is, thus, a perfect example of what I mean when I talk of a mythic-ritual poetics of archaic and classical Greek literature. ${ }^{5}$ Old Comedy is, as it is well known, a very political event as well. Therefore, the female control of the city is also projected upon the historical and political level. In this way, women are assimilated to tyrants usurping the power of the city. We have allusions to Hippias, to Harmodius and Aristogeiton, the tyrant-slayers, and, of course, to the imminent danger of an oligarchic revolution which is assimilated to a threat of tyranny. ${ }^{6}$

When one thinks of Aristophanes, one may think of freedom of speech, sexuality, and obscenity. In the Dionysiac festivals, the occasion of the yearly agon of comedy as well of tragedy and satyr-play, there is a

2 On the role of women in society and gender issues, see (e.g.) Peradotto/Sullivan 1984; Blok/Mason 1987; Winkler 1990; Späth/Wagner-Hasel 2000.

3 On the debate, see Cartledge 1997, 29 f., and n. 40 with detailed bibliography; Goldhill 1997a, 62-66. Against the opinion that women could attend dramatic spectacles and, thus, for Lysistrata played by a man with male-chauvinistic and mock-serious views, see Wilson 1982, 157-161.

4 Bowie 1993, 178-204; Martin 1987. The discussion was focused on the mythical Amazons and the Lemnians (after Burkert 1970a). See now also Reitzammer 2008 with an Adonian reading, and Gilhuly 2009, 140-179. For the religious background, see also MacDowell 1995, 239-243.

5 See Bierl 2002c; Bierl 2007a and Bierl/Lämmle/Wesselmann 2007; already Bierl 2001 (Engl. 2009a); on 'ritual poetics', see Yatromanolakis/Roilos 2003; 2004.

6 Bowie 1993, 195-199. 
lot of gaiety, phallic euphoria, and drunken excess leading to rejuvenation and revitalization. Before I come back to Lysistrata, I would like to speak about the body, body image, and corporeality that are constituents of Old Comedy.

\section{Body and the Genre}

The body and corporeality have played an important role in modern cultural studies, particularly in theatre studies, for the last two decades. ${ }^{7}$ Due to the performative turn, scholars conceive the body as the quintessential medium of energy and movement, as well as a signifying centre of Attic Old Comedy. ${ }^{8}$ Almost everything that is comic has something to do with the body, with obscenities, with the breach of behavioural norms, and with distorted gesticulation or vulgar, lowly movement.

In the following discussion, I want to consider the specific form of display of corporeality in Old Comedy. The image of the grotesque body we know mostly from Bakhtin is a feature of the genre. This folk-concept contains an ambivalent, dimorphic and fantastic body which is not closed by a clear surface but is open, protrusive and inside-out. In addition, it hyperbolically exhibits the sexual organs, the belly and the buttocks. Moreover, the grotesque body fragments itself in such a way that it seems to consist only of the above mentioned protruding parts, while it lacks a hierarchized and united perspective from head to the lower parts. Furthermore, this surrealistic and comic concept can expand to the 'people's body' or shrink to a single member. It focuses on the basic natural processes, such as eating, drinking, digestion,

7 For a survey of earlier literature, see Sullivan 1990; among others I only recall the societal approach of Marcel Mauss, Émil Durkheim and Mary Douglas, the view of an 'embodied mind' by George Lakoff, as well as the primacy of the body and the perspective of gender; in dialogue with these three traditions, one detects the image of the body in reference to the social person as advanced by Michel Foucault, as well as the theory of practice by John Comaroff and especially Pierre Bourdieu; for a summary, see Bell 1992, 94-98 (with references 152-154, nn. 111-133); see her connection with ritual in Bell 1992, 98-117; see also Neumann 2000, esp. 19-30; as far as theatre and dance are concerned, see Brandstetter 1995.

8 For the performative turn, see references in Bierl 2007a, 6 n. 22. 
excretion, and impregnation as well as other sexual activies. ${ }^{9}$ Such an idea of the body is deeply grounded in the overall grammar of the genre, which is diametrically opposed to modern, more naturalistic theatre traditions. Old Comedy was a latecomer and integrated into the competition of the City Dionysia only in 487/486 BCE. Thus, the archaia could preserve its ritual and folkloric origins much better than tragedy. It is embedded in a ritual occasion of a festival of exception in honour of the god Dionysus, particularly associated with inversion and transgression. Attic comedy stems from the kōmos, a choric and ritual group of men rioting and behaving like wild men, and the komastic choral element remains central until the end of the fifth century BCE. ${ }^{10}$ The Chorus offers the mythical background to the play, as well as giving its title. It is essential to understand that the comic choroi have their origin in ritual and remain ritualistic to a great extent. Moreover, in the culture of oral reception still broadly valid in the fifth century, the occasion is still to a large degree the genre. Thus, the festival of transgression and exception constitutes the entire notion of the play. ${ }^{11}$ Therefore, the kommos as well as the comic Chorus often impersonate ghosts, creatures of death or of the underworld. At the same time, the wild revelling group reenacts and reactualizes the liminal phase of an adolescent initiation rite. ${ }^{12}$ All in all, the genre is a hyperartificial play which, in a comic regression into atavistic times, ${ }^{13}$ produces topsyturvy counter-worlds of the 'Other' in order to unmask the theatricality of reality. Through ambivalent utopias of the Golden Age and through journeys into the underworld or heaven, the comic hero as a kind of trickster invades complementary territories, from where he, and with him the audience, can obtain power, deliverance, new energy, and rejuvenation. Such a play is grounded in archaic folk concepts of oral cultures, and by its leap into the primordial, comedy permanently reflects its origins. ${ }^{14}$

9 Bakhtin 1968, ch. 5. For some remarks on Bakhtin and his body concept in Aristophanes, see Möllendorff 1995, 74-90, esp. 74-79.

10 Bierl 2001, 300-361 (Engl. 2009a, 267-325).

11 Bierl 2001 (Engl. 2009a); Bierl 2002b.

12 Bierl 2001 (Engl. 2009a).

13 On the 'comic leap', see Lohr 1986, 63-68. On the functional and complementary approach of comedy which is based on a return to the origins, see also Münz 1998, 78, 101, 109, 118, 134-136, $151 \mathrm{f}$. and $228 \mathrm{f}$.

14 Bierl 2002a, 172 f. and Bierl 2009b, 19-26. 
Myth and ritual are fundamental means of communication, particularly in a traditional culture based on performance. By integrating myth and ritual into a dramatic plot, the polis watching the play can question and reaffirm its values and strengthen its cohesion. As a specific speech act, comedy serves as a mode of communication which by means of laughter, confusion, and perversion distorts the existing order downwards to the 'ugly' (Arist. Po. 5, 1149a32-37). In doing so, it stages obscenity and phallic rites in order make the gathered community aware of its norms in an upside down perspective. ${ }^{15}$

\section{Body and Mask}

The most important theatrical element and expedient of this sort of theatre is the mask. The actors as well as the Chorus play in body masks. They not only cover their faces with fantastic masks (in the sense of lar$v a)^{16}$ or smear them with pigments or dregs, but they also wear body stockings which wrap up and disfigure their entire human appearance in a display of grotesque signals. The comic actors' traditional outfit, with a long phallus, 'made of leather, either dangling or erect as appropriate', and the costume with a 'padded stomach and rump' are characteristic. ${ }^{17}$ The male performers could adapt this typical body mask to other roles; in this way, they could act as female figures as well, and play even 'naked' women by attaching false breasts and female pudenda. The choral dancers can impersonate all forms of the 'Other', e.g. animals, women, slaves, exotic foreigners or beings of the underworld, by assuming specific attributes. The carnivalesque distortion stressing the lower, basic body functions is underlined by other levels of signification, such as aggressive and vulgar language, mockery, and scornful derision ad personam, ${ }^{18}$ obscene expressions, and aischrology, or kinetic and gestic play. They move wildly, hop, jump, and whirl, attaining also a link to the very 'Other' by this dance expression. Corporeality

15 Brelich $1982^{3}$, esp. 112.

16 Baumbach 1995, esp. 158. On the body mask, see also Münz 1998, 109, 120, 132, 275-279.

17 Henderson 1996, 19.

18 Bierl 2002a. 
as well as ritual, folkloristic behaviour and the integration of other ritualistic forms function as generators of social and primordial energy. ${ }^{19}$

Given this polysemic bodymask, it seems improbable to suppose a form of a portrait-mask, when historical persons appear in some Aristophanic plays - Cleon in Knights, Socrates in Clouds or Euripides in Acharnians and Frogs. Of course, there has to be some form of resemblance that is reminiscent of the person suggested. Modern criticism anachronistically presupposes an equivalence of Old Comedy with cabaret or satire, and it has begun with a misconception of the archaic mask, which does not provide the bearer with a perfect new identity. Only if we see the issue from a purely naturalistic perspective, we may accept as true that a mask can conceal the proper personality. Such a view depends on the modern conception of identity, the construction of a subject and personality, and the mimesis as perfect illusion. ${ }^{20}$ In the archaic folk perspective, however, a mask means an additional level of signification, while the male civic performer always remains visible behind it. Therefore, a comic body mask has nothing in common with a modern character mask. There are not real characters and historical persons onstage either, but a Cleon or Socrates act as archetypal tricksters or as carnivalesque bōmolochoi. Bodily distortion serves as a means of reaching the complementary view on all semiotic levels.

Another feature of the functional approach to the comic genre is the use of parody, not only as a literary method in a restricted sense, but also as a cultural means of coming to terms with the complementary side of the objective, matter-of-fact reality. According to Olga Freidenberg, parody may have its origins in the sacred. ${ }^{21}$ In a traditional and ambivalent view of the world, everything sublime has its parodic and base flipside. Therefore, Old Comedy's 'indecent' attitudes do not even refrain from mocking gods and their myths.

19 On the 'circulation of social energy', see Greenblatt 1988, esp. 1-20 and Neumann 2000.

20 See Bierl 2002a, $178 \mathrm{f}$.

21 Freidenberg 1976; Baumbach 1995, 67-81. 


\section{The Female Body and the Acropolis in Lysistrata}

In the following discussion, I want to consider how the body is not only present in the mask, in movement and in verbal utterance, but even functions as the central mental image in the plot of Aristophanes' Lysistrata. $^{22}$ Women in Old comedy are shown stereotypically as body-driven beings. They are always bibulous, notoriously lewd, frivolous, and fond of sex. This gender prejudice is met by the female comic heroine; she wants to stop the terrible effects of the devastating Peloponnesian War, which is a threat to marriage, reproduction, and fertility. This deeply felt defect in the house and polis can be healed by the saviour-figure Lysistrata; she persuades the women, whom she has called from different Hellenic cities, to initiate a conjugal strike against their husbands who irrationally favour warfare.

Through the speech act of an oath acted out on the scene, she binds the lustful females to her plan (181-239). However, she is well aware that she can prevail over the men only by also taking control of the political and financial power of the city - which is exclusively dominated by males. Therefore, she orders some older women to occupy the Acropolis, the centre and divine citadel of Athens as well as the place where the public treasure used to be stored (240-246). Lysistrata stands above the base instinct of her colleagues, and directs the events with charis, rhetoric and persuasion, almost like a goddess. ${ }^{23}$ In many ways she is comparable to Athena, the mistress of the city and the Acropolis, who is magically able to compel her opponents to surrender. Specifically, she seems to be a comic equivalent to the Athena of Aeschylus' Eumenides. ${ }^{24}$

22 For recent literature on this play, see the commentaries by Henderson 1987 and Sommerstein 1990; for secondary literature, see e.g. Lewis 1955a; Hulton 1972; Vaio 1973; Rosellini 1979; Henderson 1980; Foley 1982; Martin 1987; Loraux 1981, 157-196 (Engl. 1993, 147-183); Faraone 1997; Dorati 1998 and 1999; Fletcher 1999; Grebe 1999; Perusino 1998; 1999 and 2002; Hawkins 2001; Stroup 2004; Andrisano 2007; Scholtz 2007, 71-109; Reitzammer 2008; Gilhuly 2009, 140-179.

23 On peithō, see Scholtz 2007, 83-89.

24 See the comment by the Chorus of old men (1108-1111) where iunx explicity

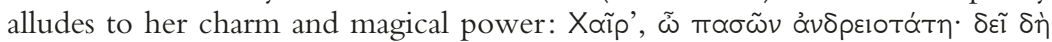

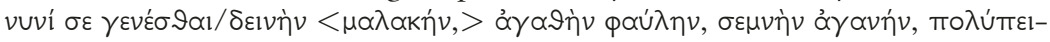

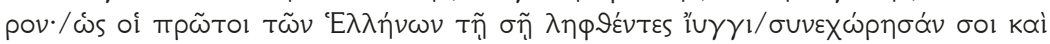

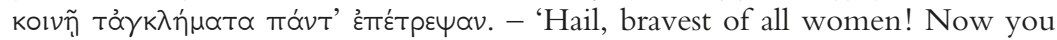
must be forceful and flexible, high-class and vulgar, haughty and sweet, a woman for all seasons; because the head men of Greece, caught by your 
Lysistrata's perceptible proximity to the eponymous polis goddess is underlined by the fact that her name may be associated with that of Lysimache, a famous priestess of Athena Polias in this period. ${ }^{25}$ Almost all the preoccupation with the basic body functions, on the contrary, is projected upon her fellows, whereas she distinguishes herself through sovereignty, intelligence and beauty. Even though she seems to be older than the young wives, she acts in a way that is beyond the age groups. The characteristic concern with the body becomes metaphorically shifted onto the locality of the events, too. Thus, the Acropolis turns into a fantastic uterus. In this way, contrary to the laws of probability, the sex strike is linked to the occupation and barricade of the holy citadel of Athens. ${ }^{26}$

The topography of the here and now adapts to the generic norms through performance and a polytropic movement of metaphor and metonymy, similarity and contiguity which are characteristic of ritual and myth. ${ }^{27}$ Rituals mostly deal with controlling the outer world and are often based on very basic objects and actions, such as drinking, eating, washing, and clothing. ${ }^{28}$ Metaphors are operational binders and shifters on which we construct and build our world. ${ }^{29}$ Metaphors and rituals are embedded in the same kind of basic language. ${ }^{30}$ Very often rituals are metaphors taken literally and performed. ${ }^{31}$ Moreover, through metaphors taken literally the poet creates his plots. ${ }^{32}$ The actual space, that

charms, have gathered together and are jointly submitting all their disputes to you for arbitration.'

25 Lewis 1955a; Connelly 2007, 11 f., 62-64, 66, 128, 130 f., 306 nn. 33-35. For priestesses on the Acropolis, see also Jordan 1979, 19-36, on Lysimache, see also Jordan 1979, 31.

26 Whitman 1964, 203 with n. 9. See the mistaken criticism by Vaio 1973, $371 \mathrm{n}$. 8. Whitman's view is confirmed by Loraux 1981, esp. 173-178 (Engl. 1993, esp. 161-166).

27 Fernandez 1977; 1986; 1991.

28 Alexiou 2002, 317-348, esp. 319-324.

29 E.g. Lakoff/Johnson 1980; Lakoff/Turner 1989.

30 Alexiou 2002, esp. 317-319.

31 Fernandez 1977; 1986; 1991.

32 Newiger 1957. For the connection between ritual, metaphor, image, and plot, see Bierl 2007a, $14 \mathrm{f}$. 
is, the Acropolis, behind the spectators assembled in the theatre of Dionysus, becomes a metaphorical space - that is, the vagina. ${ }^{33}$

In the same way as the actor's masked body oscillates between two perspectives, the self and the 'Other', the place of the fictive action to some degree always remains Athena's sacred district. The spectators seem to have automatically associated the actual rites of girls in seclusion in the cultic realm of Athena, and in particular the arrhephoroi, with women acting on the citadel. ${ }^{34}$ Thus, Lysistrata comes ever closer to Athena. This is emphasized, as noted above, by the fact that her name recalls the priestess Lysimache, who stemmed from a gentilician family. Aristophanes thus toys etymologically and metonymically with the significance of the two names, which signify the 'disbander of army/battle'. ${ }^{35}$ By the way, another key figure, Myrrhine, holds the title of priestess of Athena Nike, who was chosen by allotment. ${ }^{36}$ Through the performance, dance movements and the sung words of the Chorus, plots are created in metaphorical speech acts that correspond to these metaphorical shifts: ${ }^{37}$ the Acropolis becomes the vagina, and the sex strike (plan A) merges with the occupation (plan B). In addition, the old women become girls, and the old men increasingly become ephebes. ${ }^{38}$ The old men of the Chorus come up the steps of the Propylaia with

33 After Whitman 1964, 203 with n. 9 in more detail Loraux 1981, 174-178 (Engl. 1993, 162-166). Loraux 1981, 159 (Engl. 1993, 148) speaks of the Acropolis in this play as 'opérateur comique essentiel' ['essential comic operator'].

34 For the arrhēphoroi, see e.g. Burkert 1966; Robertson 1983; Simon 1983, 3946; Brulé 1987, 79-98; Baudy 1992.

35 Lysi- connotes also the sexual capacity to 'loosen' a man's limbs'. See Henderson 2000, 257.

36 Papadimitriou 1948-1949; see Loraux 1981, 192 (Engl. 1993, 179) and Connelly 2007, 49, 62 f., 66, 227-229, 306 n. 35.

37 Bierl 2001 (Engl. 2009a). We should not forget that the arrhepphoroi also had to execute choral dances. According to Euripides' Ion, the 'girls of Aglauros' (496) danced on the terrace of the Grotto of Pan at the north slope of the Acropolis. In this cave Creusa was raped by Apollo, and there she exposed her baby Ion as a new Erichthonius - in a basket (492-506). Referring to the same topography and ritual complex, the Ion can be regarded as a kind of tragic counterpart of Lysistrata. See also Burkert 1966, 21 (=1990, 51).

38 For the two plans, see Hulton 1972. Many critics regarded the fact that plan A is interrupted by plan B an inconsistency; see Martin 1987, 83 n. 19. On the interaction between plans A and B, see already Vaio 1973. In the comic logic apparently incongruous things without link can merge. 
huge logs and burning fire, while the women defend the blockaded narrow space: ${ }^{39}$

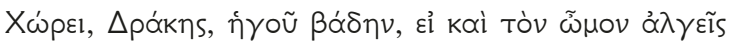

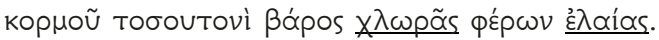

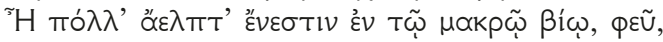

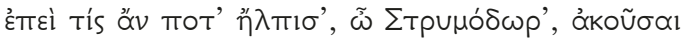

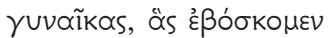

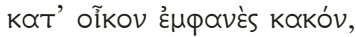

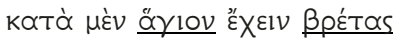

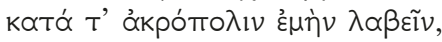

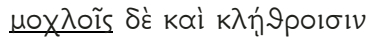

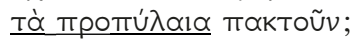

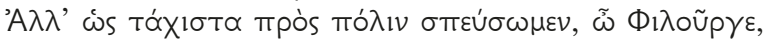

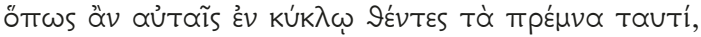

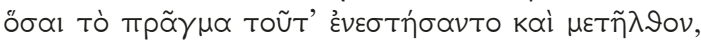

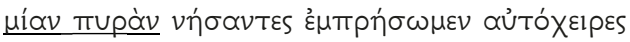

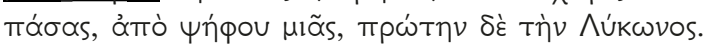

Onward, Drakes, lead the way, even if your shoulder does ache from toting such a heavy load of green olivewood.

If you live long enough you'll get many surprises, yes sir! Well, Strymodoros, who in the world ever thought we'd hear that women, the blatant nuisance, we've reared in our homes now control the Sacred Image and occupy my Acropolis, And to top it all, with bolts and bars close off the citadel gates?

Let's hurry to the Acropolis, Philourgos, full speed ahead, so we can lay these logs in a circle around all the women who have investigated or abetted this business. Let's erect a single pyre and incinerate them with our own hands, all of them on a single vote, starting with Lykon's wife!

The men are reminiscent of the phallophoroi, carriers of oversized phalluses, threatening female chastity by coming up the steep and narrow passage of the Propylaia. Accordingly, the ithyphallicus as rhythm of their song fits their phallic role. Moreover, burning fire symbolically reflects the sexual drive of the exclusus amator. ${ }^{40}$ In order to understand the symbolic fusion of female genitalia and the Acropolis, which can be ach-

39 For this and the following quotations, I cite the Greek text from Coulon (with some changes) and the (slightly modified) translation by Henderson 2000. Underlined words give special emphasis to our thematic context.

40 See Faraone 1997; Dorati 1999; Perusino 1999. 
ieved by resemblance and performative assimilation, it is useful to cast a glance at the map (fig.1, next page). ${ }^{41}$

The audience sitting in the theatre of Dionysus have the Acropolis to their back. In a process of mental mapping, the spectators project themselves into this holy place with which they are all familiar. According to generic laws, mental mapping shifts to comic body mapping in the festival of exception. In other words, we could also talk about an iconic poetics of Lysistrata, according to which the performance works by images, by cognitive experiences of scanning public, holy and private space in mental pictures.

\section{A Mythic-Ritual Poetics of Lysistrata: Playing the Maiden or, New Year and Initiation}

At the same time, body, and space are translated into mythic-ritual discourses. Polis, oikos, and body are comically merged. If women take action on the Acropolis and deny their sexuality, they are associated either with mythical models of a counter-world gynaecocracy or especially with the arrhêphoroi, young girls who devote almost nine months on the Acropolis in cultic service to Athena Polias. Lysistrata is thus based on the heortological sequence in the Athenian festival calendar from the Skira to the Panathenaia, a course reaching from premarital rites to marriage. Although Athena is the primary divine reference, the play represents also a process from Athena/Artemis to Mighty Aphrodite. The goddesses, especially Athena and Aphrodite, in an interdependent way, remain decisive for the play's trajectory. ${ }^{42}$ In the logic of comedy, the refusal of sexual intercourse by baring the body becomes equivalent to the return to the status of a maiden who has to face the crisis of a rite of passage in order to become a woman. The strange rites ranging from the Arrhephoria to the Panathenaia not only focus on the initiation of young men and women, but are also about the critical transition from the old year to the new, and about the harvest and vegetation. Thus, initiation, new year, and fertility, all three paradigms

41 The map (fig. 1, next page) with the numbering is taken from Travlos 1971a (Engl. 1971b), 71. Loraux 1981, 161 (Engl. 1993, 150) produces a similar map.

42 Elderkin 1940; Loraux 1981, 157-162 (Engl. 1993, 147-151); for the role of Aphrodite, see Stroup 2004 who argues that the women become hetairai. See also Reitzammer 2008, 296-300. 


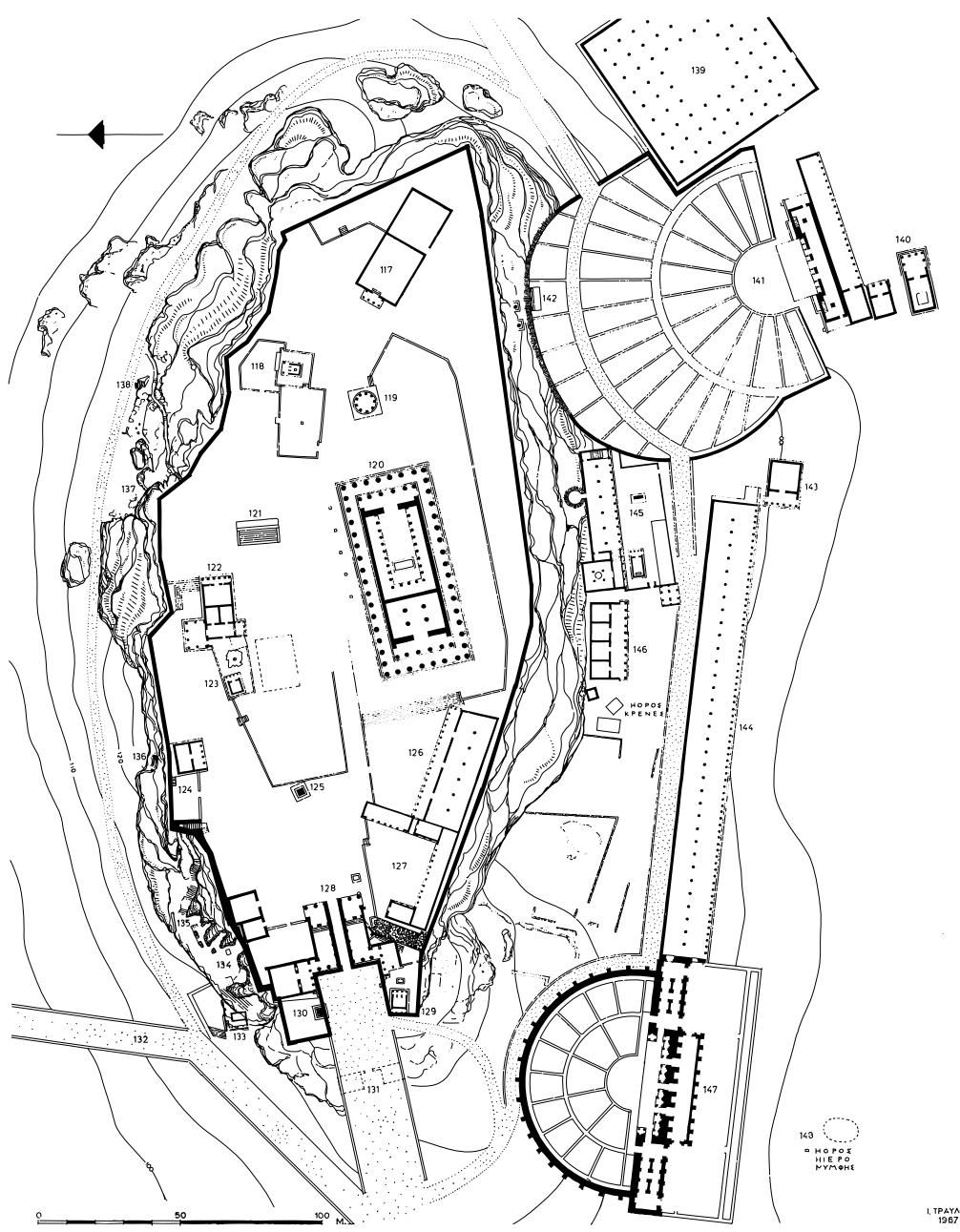

120: Parthenon - 121: Altar of Athena - 122: Erechtheum - 123: Pandroseion - 124: House of the Arrhephoroi - 125: Athena Promachos - 127: District of Artemis Brauronia - 128: Propylaia - 129: Temple of Athena Nike - 132: Panathenaic Way - 133: Klepsydra - 134: Apollo Hypoakraios - 135: Cave of Pan - 136: Cave of Aglauros - 137: District of Eros and Aphrodite - 141: Theatre of Dionysus

Fig. 1: Lysistrata and the Topography of the Acropolis: Selected Landmarks Legend 
of the modern interpretation of religion, are intertwined..$^{43}$ Athena represents the mythical origin of polis history, the foundation of civilization, and the invention of agriculture, and many central myths - I need mention only the daughters of king Cecrops - partially accompany the famous festivals and ritual practices around the end of the year pari passu. ${ }^{44}$

As I said, the actions of the old women on the Acropolis are fused with premarital rites of initiation for young girls. The women symbolically return to the state of ritual maidens of Athena, and comically reenact or reactualize the arrhêphoroi (see the House of the Arrhephoroi MAP 124). By playing, dancing, washing, and woolworking, they receive a sort of symbolic education in sexuality. At the Chalkeia, in late autumn, on the 30th of Pyanopsion, two young girls at the tender age of between seven and eleven, who represent all maidens, would enter into the service of Athena on the Acropolis. As ergastinai, they were chiefly concerned with the making of the peplos for the goddess, which is then presented to her at the subsequent Panathenaia at the end of July (28th of Hekatombaion), a festival at which the young people present themselves for marriage. ${ }^{45}$ Therefore, Lysistrata applies the famous woolworking or weaving-metaphor - the women prepare a chlaina (586) - for the execution of govermental functions in the city $(567-586) .{ }^{46}$ In addition, their playing and dancing is projected onto the constitutive action of the actual female Chorus. In a famous passage Pausanias (1.27.3) reports on the arrhepphoroi. For almost nine months they fulfil this ritual duty, in the eighth, at the Arrhephoria, they carry some objects in baskets down on secret ways along the northern slope of the Acropolis. These objects have to do with a first encounter with sexuality on a symbolic and educational level and with agricultural and human fertility. In a container, kistēe, they carry a knife, perhaps a

43 Bierl 2007a, esp. 11, 23-30; for a 'polyparadigmatic approach', see Versnel 1993, esp. 12.

44 Burkert 1966; see the discussion by Versnel 1993, 15-88, esp. $51 \mathrm{f}$.

45 See also Loraux 1981, esp. 174-178 (Engl. 1993, 162-166); for a similar return in time in Ar. Thesm., see Bierl 2001, 225-287, esp. 267, 276-287 (Engl. 2009a, 196-254, esp. 235, 244-254), based on a similar view on the festival of the Thesmophoria by Versnel 1993, 235-288. I have just presented a paper on this aspect regarding E. Hel. and it will be published soon.

46 See also Loraux 1981, 188 (Engl. 1993, 175). For the interpretation of the wool-metaphor, see Moulton 1981, 48-58; on the motif of weaving in this comedy, see Dorati 1998, esp. 44-50. On the metaphor of woolworking and spinning in connection with female initiation, see also Ferrari 2002, $11-60$. 
model of a phallus or snake representing Erechtheus, and probably figures of dough such as cunnus and phallus, a mini-plough and grain, without knowing the hidden contents. In a cleft with a steep staircase they descend from the yard of their house (MAP 124) to the Grotto of Aglauros (MAP 136) near the Shrine of Eros and Aphrodite, probably the KñTol 'Apposítns (MAP 137) beneath the northeast corner of the Erechtheum, to some subterranean place, a vault formed by nature

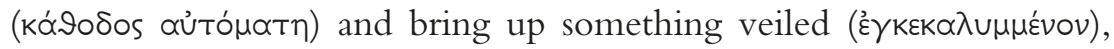
representing a baby, the newly born Erichthonius (cf. Paus. 1.27.3). Obviously in the cave they lay down the kiste, open it and handle the mystic objects as a programme for learning sexuality in an uncanny atmosphere. Symbolically they experience in a condensed form the process from conception to birth, from sowing to harvest. ${ }^{47}$ There is a dispute as to whether the sanctuary of Aphrodite in the Gardens was the destination, an identified sanctuary at the bottom of the north slope

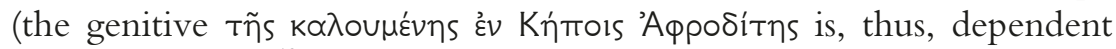
from $\pi \varepsilon p i \beta o \lambda o s),{ }^{48}$ or if the genitive depends on ou móppw and the end of their way would only be close by the Gardens of Aphrodite, thus further down, maybe even to the sanctuary of the same name at the river Ilissus, around the corner of the Acropolis through the Aglaureion, in the southeast. ${ }^{49}$

The steep northwest slope of the Acropolis seems to be the background of the scene where the phallic Kinesias is duped by his wife Myrrhine. The impressive staging of the sex strike is located in the Grotto of Pan (MAP 135), near Apollo Hypoakraios (MAP 134) and Klepsydra (MAP 133) beneath the Propylaia (MAP 128). ${ }^{50}$ Myrrhine can use another steep staircase which leads down at the northwest slope to the Cave of Pan along the shrine of Apollo to the Klepsydra. ${ }^{51}$ Already in the scene before, Lysistrata describes her precarious situation. The male view of the females, that they are just voluptuous and sexdriven beings, is comically confirmed, because it seems as if she cannot hold them back any more from deserting. Before three attempts at fleeing home to their men are acted out on stage (728-780), Lysistrata re-

47 Baudy 1992, 34.

48 Burkert 1966, 2 (= 1990, 41); Travlos 1971a (Engl. 1971b), 228-232, esp. 228 f. with fig. 293.

49 See Baudy 1992, 7. For the latter solution, Robertson 1983, 251-255 and Brule 1987, 89 f.; for the way 93-95.

50 Travlos 1971a (Engl. 1971b), 417-421; 91-95; 323-331.

51 Travlos 1971a (Engl. 1971b), 93 fig. 116. 
ports on such cases. One was caught just at Pan's Cave excavating the

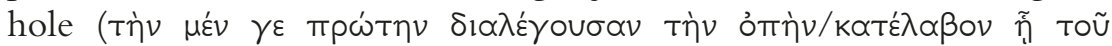

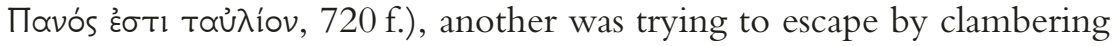
down a pulley cable, another wanted to fly away, and all the women find all sorts of excuses (717-727). Then several wives appear on scene to act it out $(728-780)$; one wants to go to her woolwork, the other to her flax, one pretends to deliver, pregnant with a helmet of Athena; she insists that she has a baby like a pigeon; then she says she cannot sleep any more since she has seen the temple snake. ${ }^{52}$ On the basis of the difficult scholium on Lucianus DMeretr. 2.1 (275.23276.28, esp. 276.8-17 Rabe) and myths pari passu, we recall that the girls are shocked in the underground by snakes and phalluses at night. ${ }^{53}$ Finally Lysistrata produces a 'pretty explicit oracle' (777) in sexual terms to manipulate her comrades: the swallows should flee the hoopoes and leave the phallus alone until Zeus shall reverse what is up and what is down - a sign for the upside-down perspective of comedy. If the swallows begin to argue and fly away from the holy citadel, then this bird will be called the most disgustingly horny of all (770-776). Thus, she can convince them to stay.

The choral interludes, in the form of competitive and recriminatory songs of exchange (amoibaia) after the comic attempts to escape, use mythic examples to underline the men's hatred of the female sex (Melanion),$^{54}$ and one man's contempt for other men (Timon) $(781-828) .{ }^{55}$ However, whereas the half-Choruses have been decisive in the agonistic action until this point, they are less involved in the plot from now on, and comment only on what happens.

I cite a passage from the funny scene between Kinesias and Myrrhine (829-953) after the interlude. Lysistrata's plan A, after its interweaving with plan $\mathrm{B}$, is impressively brought to the fore again and successfully acted out in the famous landscape of the north slope onto which the young maidens descend. The location of the frustrated love is the Cave of Pan (MAP 135), and even the Klepsydra (MAP 133) is mentioned:

52 On lines 740-752 with Athena and her rites at the focus, see Bodson 1973.

53 For the snakes, see Robertson 1983, 256-265; more convincing is Brulé 1987, $91 \mathrm{f}$.

54 On the motif of the Black Hunter, see Vidal-Naquet 1986b.

55 Hawkins 2001. 


\begin{tabular}{|c|c|}
\hline MY. & 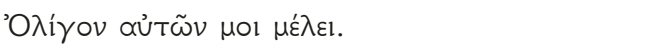 \\
\hline $\mathrm{KI}$. & 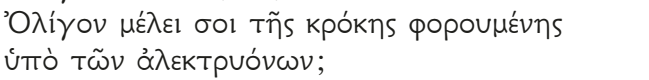 \\
\hline MY. & 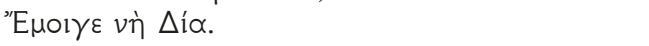 \\
\hline $\mathrm{KI}$. & 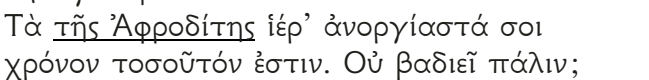 \\
\hline MY. & 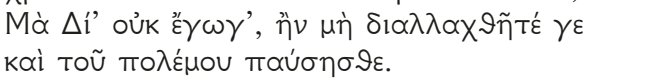 \\
\hline $\mathrm{KI}$. & 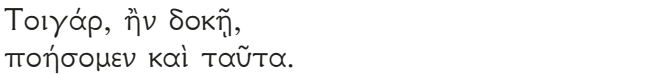 \\
\hline MY. & 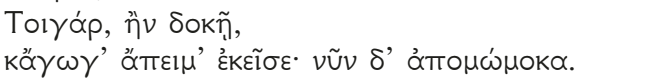 \\
\hline KI. & 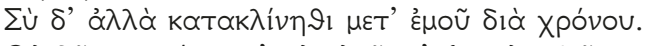 \\
\hline MY. & 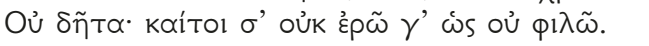 \\
\hline $\mathrm{KI}$. & 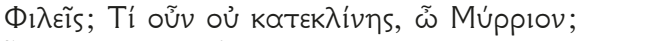 \\
\hline MY. & 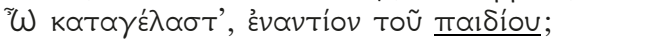 \\
\hline KI. & 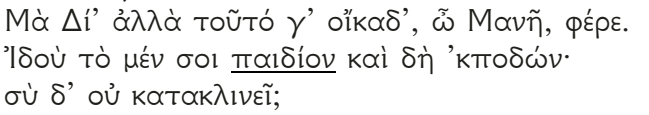 \\
\hline M) & 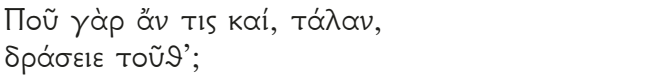 \\
\hline KI. & 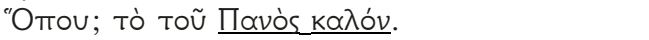 \\
\hline MY & 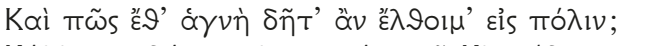 \\
\hline $\mathrm{Kl}$. & 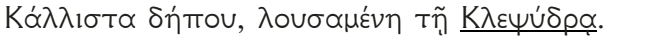 \\
\hline MY & 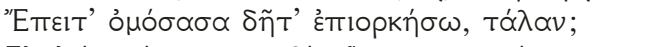 \\
\hline KI. & 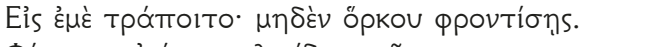 \\
\hline MY & 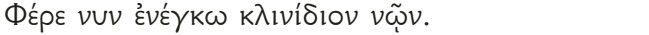 \\
\hline
\end{tabular}

Myrrhine It doesn't bother me.

KinESIAS It doesn't bother you that the hens are pulling your woolens apart?

Myrrhine Not a bit.

Kinesias And what a long time it's been since you've celebrated Aphrodite's holy mysteries. Won't you come home?

Myrrhine I certainly will not, not until you men agree to a settlement and stop the war.

Kinesias All right, if that's what's decided, then that's what we'll do.

Myrrhine All right, if that's what's decided, then I'll be coming home. But meanwhile I've sworn to stay here.

Kinesias But at least lie down with me; it's been so long.

Myrrhine No, I won't. But I'm not saying I don't love you.

Kinesias You love me? Then why not lie down, Myrrie?

Myrrhine You must be joking! Right here in front of the baby?

Kinesias Of course not! Manes, take it home.

There you are, the kid's out of the way. Won't you lie down?

Myrrhine But my dear, just where could a person do it? 
Kinesias Where? Pan's Grotto will do fine.

Myrrhine But how could I go back up to the Acropolis no longer pure?

Kinesias Very easily done: just wash off in the Klepsydra.

Myrrhine You're telling me, dear, that I should break the oath I swore?

KINESIAS Let that be on my head; don't you worry about any oath.

Myrrhine All right then, let me fetch us a bed.

Lysistrata appears on the roof - like an Adoniazousa - and yells. ${ }^{56}$ Kinesias, a man with erection, the literal 'Fucker' ${ }^{57}$, comes from the sancturary of Demeter Chloe (835, see Paus. 1.22.3). It is a possible candidate for the location of the final destination of the arrhepphoroi, while the name might allude to the greenish seedlings. ${ }^{58}$ Kinesias shows up with their baby. His wife Myrrhine - who has the aphrodisiac myrtle in her name, bearing obscene connotations ${ }^{59}$ - lives up to the oath of the sex strike by frustrating Kinesias' hopes with an endless comic deferral of the intercourse that is supposed to take place in the bucolic Cave of Pan. The wrapped child whom the arrhepphoroi carry up is transposed to a family scene ${ }^{60}-$ Myrrhine seems younger and more attractive to the husband ( 885 f.), an allusion to her return to the maiden status. Moreover, she again excuses herself with woolwork (896 f.). Kinesias refers to Aphrodite's mysteries - these are the rites at the north slope (898 f.). The deferred love scene takes place in the Grotto of Pan (911), and in the nearby Klepsydra (913) she prepares her symbolic bridal bath. Then, she excuses herself to fetch a klinidion - her whole sexual operation might be similar to the handling in the kistê. Having prepared the bed, Myrrhine wants to have perfume, uúpov (938, 940, 942); because of the waste of time, however, the scent, according to him, is

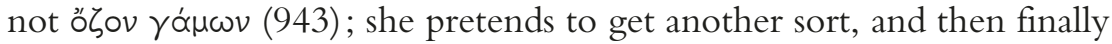
she leaves him.

From the beginning, the sex strike is planned in such a way that the interruption of sexual relations between husband and wife does not lead to a final separation. Instead, the men are to feel special desire for their

56 Similarly now also Reitzammer 2008, esp. 300-304, who interprets, however, the Acropolis as a notional rooftop, and provides an entirely Adonian reading (also for the oath, esp. 'the boar' [202], cosmetics, myrrh).

57 Henderson $1991^{2}$, 35, $151 \mathrm{f}$; on sex in agricultural terms, Henderson 1991², 166-169. On Lys., see Henderson 199122, 93-99.

58 Baudy 1992, 38 n. 206. On Demeter Chloe and the Chloia, see also Kledt 2004, $148-152$.

59 Henderson $1991^{2}$, $134 \mathrm{f}$. See also Stroup 2004, 59. For the entire scene, see Stroup 2004, 56-62.

60 See Elderkin 1940, esp. 394 f. 
partners through their erotic appearance and thereby succumb to their sex appeal (42-53, 149-154, 217-222). Through extreme seduction and, at the same time, constant sexual frustration, as shown above, the exclusi amatores are to finally agree to conclude a peace deal with one another. Therefore, the women have to dress in a special and fancy way to be sexually attractive. By putting on a ritual krokōtos, ${ }^{61}$ a saffron-yellow dress, here particularly transparent, Lysistrata explains to Kalonike how they should attain their goal:

\begin{tabular}{|c|c|}
\hline $\mathrm{K} \wedge$. & 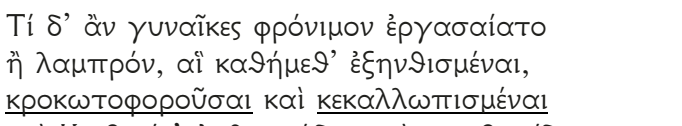 \\
\hline Y. & 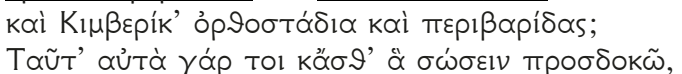 \\
\hline 1. & 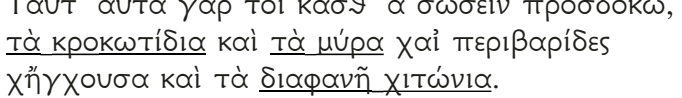 \\
\hline K^. & 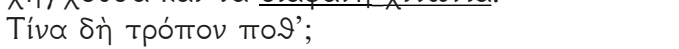 \\
\hline$\Lambda Y$ & 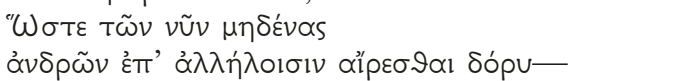 \\
\hline $\mathrm{K} \bigwedge$. & 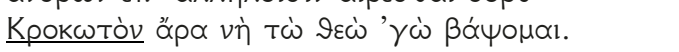 \\
\hline$\pi$ & 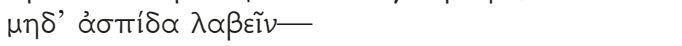 \\
\hline KA & 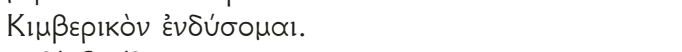 \\
\hline & 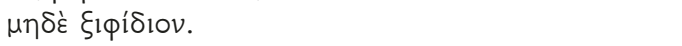 \\
\hline K^. & 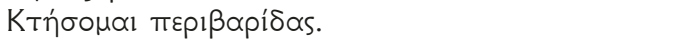 \\
\hline
\end{tabular}

KALONIKE But what can mere women do that's intelligent or illustrious? We sit around the house looking pretty, wearing saffron dresses, and make-up, and Kimberic gowns, and pleasure-boat slippers.

Lysistrata Exactly! That's exactly what I think will rescue Greece: our fancy little dresses, our perfumes and our slippers, our rouge and our see-through underwear!

KalONiKe Just how do you mean?

Lysistrata They'll guarantee that not one of the men who are still alive will raise his spear against another-

Kalonike In that case, by the Two Goddesses, I'll have a dress dyed saffron!

LySISTRATA nor hoist his shield-

KalONiKe I'll wear a Kimberic gown!

61 Lines 44, 47, 219 f.; see lines 48, 150 f. See Hamilton 1989, 461 with n. 28. For an interesting connection between the Arkteia, the krateriskoi at Brauron, Lys. 645, and Alcman, see Hamilton 1989, esp. 462-471. For the krokotos, see also Andrisano 2007, 9-15. 
LySISTRATA nor even pull a knife!

KaLONIKE I'll go shopping for slippers!

Then Lysistrata, the director of the intrigue, makes her plan even clearer:

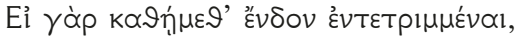
Kởv Toĩs XIT

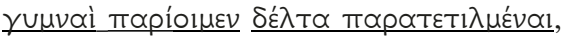

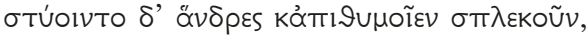

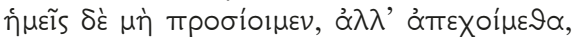

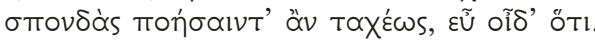

If we sat around at home all made up, and walked past them wearing only our diaphanous underwear, with our pubes plucked in a neat triangle, and our husbands got hard and hankered to ball us, but we didn't go near them and kept away, they'd sue for peace, and pretty quick, you can count on that!

The krokottos recalls the Brauronia, another similar rite of passage of very young girls, probably between five to ten, or better ten to fifteen years of age before they reach marriage, ritually taking place at the Panathenaia. ${ }^{62}$ The Brauronia culminated in the ritual of the bears (Arkteia) in which the girls took off their saffron-robes and ran and danced naked. ${ }^{63}$ As I said, the metaphorical shift from the occupied citadel towards a fantastic womb which refuses access to the phallus makes the old women change into these chaste maidens for whom having sex before marriage is forbidden. However, the ritual robe is comically shifted to an urban dress of hetaeric seduction. ${ }^{64}$ The cursus honorum in the city's 'splendid education', from arrhēphoros, to aletris, to a girl of Brauron and, last but not least, to a Panathenaic kanepphoros, is directly referenced in the famous ode of the women in the parabasis (636-648). The women, in their bitter fight with words and deeds, ${ }^{65}$ stress their honour in having fulfilled these sacred rites for the city:

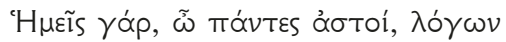

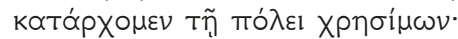

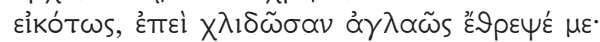

62 Former: Sourvinou-Inwood 1988, 130-134 after scholium on Lys. 645; later: Grebe 1999 after Perlman 1983, esp. 116 f. and Perlman 1989, esp. 123 n. 51.

63 See Brulé 1987, 225-261; Gentili/Perusino 2002; Perusino 2002. On the relation of the Arrhephoria to the Arkteia, see Sourvinou-Inwood 1988.

64 See Stroup 2004.

65 Perusino 1999, esp. $77 \mathrm{f}$. 


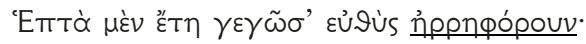

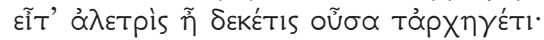

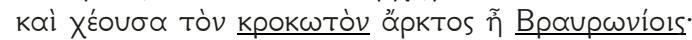

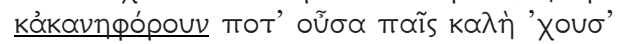

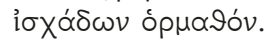

Citizens of Athens, we begin

by offering the city valuable advice,

and fittingly, for she raised me in splendid luxury.

As soon as I turned seven I was an Arrhephoros;

then when I was ten I was a Grinder for the Foundress;

and shedding my saffron robe I was a Bear at the Brauronia; ${ }^{66}$

and once, when I was a fair girl, I carried the Basket,

wearing a necklace of dried figs.

Thus, we see that these sacred premarital rites of young girls are central. It is not by chance that they are explicitly mentioned. In this way, besides Aphrodite, Athena, and Artemis - as well as the rites of her maidens - they become key motifs in the play. The kanephoric rite at the Panathenaia structurally repeats the Arrhephoria. ${ }^{67}$ Instead of dying immediately after the opening of the kiste of Erichthonius, in Ovid's Metamorphoses 2.708-832 the Cecropids live on and serve later as kanepphoroi. As basket-carriers they meet the ephebes, their potential partners in marriage. In their baskets are grain seed and a phallic knife. In myth, Hermes falls in love with Herse and makes her pregnant: she gives birth to a child, a mythic precursor of Adonis (Apollod. Bibliotheca 3.14.3). In addition, the kanēphoros Oreithyia, a daughter of Erechtheus, is snatched away by Boreas at the Panathenaia to the Black Sea, where he makes her his wife (Akousilaos of Argos, FGrHist 2 F 30). ${ }^{68}$ The function of looking for a wife is underlined by choroi on the Acropolis (E. Heracl.777-783). In Lysistrata, the oikos, the polis, and female body merge. The women want to escape from seclusion on the Acropolis with openly sexual pretences. Lysistrata as a clever, intelligent dou-

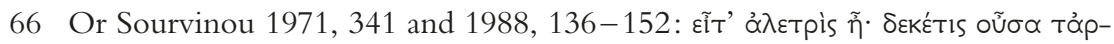

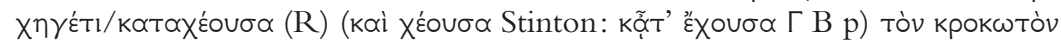
œ̊рктоs ர̃ Bpaupwviols. - 'then I was Grinder; when I was ten, I shed /I wore my saffron robe for the Foundress (= Artemis) at the Brauronia'. Against Sourvinou-Inwood's textual conjecture, see Grebe 1999 and Perusino 2002. Ac-

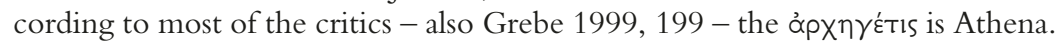

67 Baudy 1992, 42-45.

68 See Baudy 1992, $43 \mathrm{f}$. 
ble of the goddess can manipulate them by charis, rhetoric, and the invention of an oracle.

\section{Heortological Facts: Skira, Arrhephoria, Adonia, War, and the Seed Box}

As I have argued, Lysistrata is based on the course of girls' rites ranging especially from Skirophorion 12th to the Panathenaia. ${ }^{69}$ These rituals function by an isomorphic polyfunctionality, bringing together aspects of new year, puberty initiation, and agricultural fertility, all acted out on the body and its somatic symbols. Moreover, the female rites are synchronized with male rites of maturation leading to the ritual marriage at the end of the play. ${ }^{70}$

Lysistrata is constituted by a web of ritual allusions which produce a complex symbolic sense on the level of sexuality and reproduction.

Fig. 2: Some Ritual Landmarks in the Plot of Lysistrata

1-5: Rites of Bacchus and Aphrodite - rites of married women. Grotto of Pan, celebration at Kolias; Genetyllis, associated with childbirth. At Nub. 52 Aphrodite Kolias and Genetyllis are favourites of Strepsiades' sensual and extravagant wife.

42-47, 219 f.: Krokōtos.

188: Sacrifice; epiboion for Pandrosos.

Parodos: Choral dance and ritual action: male thallophoroi vs. female skaphephoroi (or hudrophoroi) at the Panathenaia, Panathenaic fire: fire against water. Girls fetching water from the Enneakrounos-Kallirrhoe at the Ilissus river: water and washing, water and marriage, Plynteria, the watering of the gardens of Adonis and the dew of the arrhephoroi, carrying something to the surroundings of the Ilissus; the watering of Erechtheus, the birth of Erichthonius.

389-398: Adōniasmos (ca. July 20th): gardens of Adonis back on the roofs, death and ecstasy. The death of Erechtheus/Adonis/Osiris Adoniazousai scholium on Lys. 389.

397: Cholozuges-Bouzuges.

435, 443, 447: Artemis.

439: Pandrosos.

567-586: Wool-metaphor: women in power; polis and oikos, weaving of the peplos on the Acropolis.

638-647: The public role of the women in terms of ritual activity. Arrhēphoros, aletris, playing the bear at Brauron, kanēphoros.

69 Burkert $1966(=1990,40-59)$ and Burkert 1983, esp. 135-161.

70 See Baudy 1992, 40-42. 
721, 911: Sexual activitiy near the Grotto of Pan.

Kinesias and Myrrhine at the north slope: comic re-enactment of arrhephoric rites.

913: Klepsydra.

1106-1188: Diallage and the female body, Greece as a sexual landscape. Exodos: Choral dance and Spartan re-enactment of rites of passage in Spartan scenery (Leucippides and Helen). Reference to Alcman; Athena as reconciliatory goddess; return to marriage and sexuality.

We can see that the action is framed by choral and Bacchic dances (1, 1281-1284, $1312 \mathrm{f}$.); in the beginning, the women act out their sexuality, then they reenact their maiden phase, and at the very end, they are on the verge of symbolically remarrying again, celebrated with a mix of Spartan and Athenian choroi. In the final songs (1273-1294, 12961321) we find a correspondence of Spartan and Athenian cults of transition culminating in a civic new year's festival, especially under the protection of Athena, who functions as central polis-goddess in both cities. I have shown in detail elsewhere how Aristophanes intertextually - or better inter-ritually or -chorally - alludes to the model of the famous Spartan partheneia of Alcman. ${ }^{71}$ In doing so, Aristophanes symbolically conveys the meaning of remarriage and return to adulthood, normality, and peace. The Panathenaia might be paralleled with the Spartan Hyakinthia, perhaps also partially with the Gymnopaidiai and Karneia. At the Hyakinthia, choral dance served as a preparation for marriage and the selection of a bride (Polycrates FGrHist 588 F 1 cited in Ath. 139c-f); at the Gymnopaidiai, it is a more symbolic expression of the marginality of the transitional phase using body language (Pl. Lg. 633c; Plu. Ages. 29.2 f.; Paus. 3.11.9); at the Karneia, by contrast, the activity of the Chorus members underscores renewal (E. Alc. 445-451) and collective marriage. ${ }^{72}$ In the case of the Spartan festivals of the Hyakinthia, Gymnopaidiai and Karneia, Pettersson assumes a festive cycle, comparable to the Athenian new year cycle in July/August. ${ }^{73}$ Perhaps it is wiser to emphasize only a certain parallelism of the Panathenaia with the Hyakinthia. ${ }^{74}$

71 Bierl 2007b (= Engl. [forthcoming]).

72 Choruses of men and women dance together in Cyrene; Call. Ap. 71-87.

73 On the festive cycle in Sparta, see Pettersson 1992, passim, especially on choral dance at the Gymnopaidiai, ibid. 45-55; at the Karneia, ibid. 77.

74 Among others neaniskoi danced at the Hyakinthia. The eirenes (twenty-yearolds) received a red cloak and a shield as token of their new military status (Xen. Lac. 11.3). Pettersson 1992, 38-40 also connects the Hyakinthia with fe- 
In between the beginning and end of Lysistrata, the typical comic regression takes place, the return of women to maidens, the dissolution of marriage, oikos, and polis. In the context of the reversals of the normal order at the end of the year in June, on the day of the Skira (12th of Skirophorion) the priestess of Athena Polias, the priest of PoseidonErechtheus, and the priest of Helios, under the cover of a white canopy carried by one of the Eteoboutadai, march in procession from the center of the polis, the Acropolis, to the periphery on the border of Attika, to Skiron, located near Eleusis, just before the Cephisus river.

In this hostile atmosphere, a kind of war is staged between males and females. In the comic play, the agonistic fight between the sexes is acted out on a performative level through the violent confrontation of two semi-Choruses and their final reunion, which is also blended with a peaceful reunion between the Spartans and Athenians. On the personal level, we find dispute, battle, and debate as well. I need only recall the tirade of the proboulos $(387-423)$, his attack on the citadel (424-466), and the debate as an official agōn between Lysistrata and the proboulos $(476-613)$.

As I have noted, the rituals are also related to grain and reproduction. At the Skira, a festival which took place in June and also had a heortological connection to the central practices of the Thesmophoria, women threw 'piglets' and other fertility-inducing objects, such as cakes in the form of snakes and male genitalia as well as pinecones and twigs, into subterranean pits ( $\mu \varepsilon \dot{\gamma} \alpha \rho \alpha)$. The 'decomposed' remnants were then brought up at the Thesmophoria in October to be added to the earth at the sowing of crops. ${ }^{75}$ The Skira belong to the rites of the Arrhephoria and structurally anticipate the Thesmophoria. ${ }^{76}$ In particular, women gathered together both at the Skira and at the Thesmophoria, with

male initiation rites: he associates the triad Demeter-Kore-Pluto on the altar at Amyklai, as described by Pausanias (3.19.3-5), with Polyboia's transition from the status of maiden to adult woman.

75 Given the highly unclear nature of the scholium to Lucianus DMeretr. 2.1 (275.23-276.28 Rabe) there is still a debate about which festival of Demeter this rite of casting away (276.1-3 and 19) was performed at.

76 See Harrison 1922 $2^{3}, 131-135$; Baudy 1992, esp. 22 f. and Camps-Gaset 1994, 142-144. Scholium on Lucianus DMeretr. 2.1 incorrectly collapses 'Arrhetophoria/Arrhephoria/Skirophoria and Thesmophoria' into one, which clearly goes back to an abbreviated comparison based on an analogy of summer and autumn rituals. On the Skira, see also Calame 1990, 339-354, and in general (in connection with the structure of the festival and symbolic spatial partitioning of Attica) Calame 1990, 289-396. See also Kledt 2004, 152-187. 
men being excluded in both cases. ${ }^{77}$ The Arrhephoria, like the Thesmophoria, restaged the myth of the abduction of Kore, the young maiden par excellence, by Hades. Moreover, the day of the Skira is associated with masculine war, recalling our current Peloponnesian War between Athens and Sparta. In myth, the legendary battle between Athens and Eleusis, in which the Athenian king Erechtheus was killed by Poseidon, took place on the Skironian field. ${ }^{78}$ On this day too, Agraulos, a daughter of Erechtheus, sacrificed herself for her homeland because of an oracle, and her sisters shared her lot. According to Euripides' Erechtheus, the Athenians worshipped the maidens under the name of the Hyacinthides with yearly rites and festive dances (fr. 65.68-80 Austin $=$ fr. 370. 68-80 Kannicht). Their sacrificial death corresponds to the fall of the daughters of Cecrops from the Acropolis, which serves as the aition for the practices at the Arrhephoria. ${ }^{79}$ It was at the sanctuary of Agraulos/Aglauros that ephebes would take their oath to defend the fatherland, as symbolized in its agrarian fruits. ${ }^{80}$ The oath of Agraulos might be comically referenced in the famous oath-scene as well (181-239). Mock battles of ephebes - all men also symbolically return to ephebes in Lysistrata on the Skironian field correspond to the mythical model. The death of Erechtheus and his warriors is paralleled by the harvesting of the sacred crops there, and is analogous to the death of the ephebe who rises once more like Erechtheus in the form of Erichthonius. Besides the conflict between Athens and Eleusis, there were other mythical and historical battles that served as possible aitia for ritual two-sided 'wars' ${ }^{81}$ In particular, the ephebes believed they were reenacting the most famous of all wars, the Trojan conflict. The epoch-making conquest of this

77 See IG II/III ${ }^{2} 1177=$ LSCG n. 36.8-13 (Thesmophoria and Skira are named as one of the festivals at which separate assemblies of women were held). In Ar. Ec. 18 the women plot their take-over while assembled at the Skira.

78 The priest of Poseidon proceeding from the Erechtheum represented Poseidon and his opponent Erechtheus in the same person.

79 See Philochorus FGrHist 328 F 105.

80 See the text in Siewert 1977, $102 \mathrm{f}$.

81 Baudy 1992, 18-20. He (14-17) convincingly does not place the Arrhephoria before the Skira, as does Burkert 1966, 5 n. 2 (= Burkert 1990, 54 n. 8) on the basis of a sacrifice in Erchia which fell on the third day of Skirophorion, but also dates it to the twelfth of Skirophorion. For as Baudy says, the birth of Erichthonius, which was celebrated at the Arrhephoria, could hardly have been before the death of Erechtheus (12th Skirophorion), whose symbolic reincarnation Erichthonius after all represents. See also Kledt 2004, 169-173. 
city was dated to the 12th of Skirophorion (Clem. Al. Strom. 1.104), as was the historical battle at Mantinea (Plu. De glor. Athen. 7, 350a). ${ }^{82}$

The swaddled baby Erichthonius as the rebirth of the dead Erechtheus is the mythic exemplum for the male initiate who attains manhood at the Panathenaia. The rite of the Arrhephoria is - in symbolic form - a representative initiation of prepubescent girls into the mysteries of sexuality and agriculture. The baskets of Erichthonius form the model for the plant beds through which the functions of sowing, harvest, procreation, and birth are experienced in a preparatory fashion..$^{83}$ The kiste with the baby is identical to the coffin of Erechtheus. Sometimes it is called a larnax. In the agon with the old proboulos, Lysistrata finally cuts him off with the words: 'Why don't you just drop dead? Here's

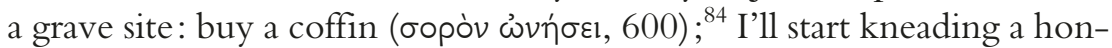
eycake. Use these for a wreath.' (599-602) ${ }^{85}$ After the first round, she has given him a veil and a sewing basket (530-538). As an old man, he is almost equated with Erechtheus. How much marriage and reproduction count for the women becomes obvious by Lysistrata's remark where she contrasts the situation of men with that of women (594597):

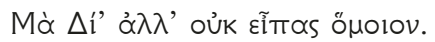

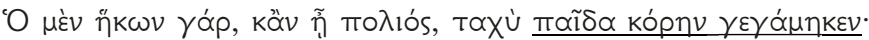

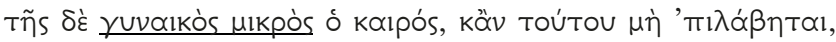

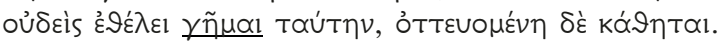

That's quite a different story. When a man comes home he can quickly find a girl to marry, even if he's a greybeard. But a woman's prime is brief; if she doesn't seize it, no one wants to marry her, and she sits at home looking for good omens.

The boxes served as test beds for the seed grain, and they were equivalent to the gardens of Adonis and the coffins of Osiris. ${ }^{86}$ The arrhephoroi descended and deposited the baskets near the Gardens of Aphrodite. In one night, they exprienced the whole cycle from sowing to harvest, and from symbolic intercourse to birth, as they played around with symbolic

82 See Baudy 1992, 19 and Burkert 1983, 158; significantly, the Spartans dated the sack of Troy to the Karneia.

83 See Baudy 1986, 9-48 and 1992, 31-40.

84 At line 372 the Chorus of the old men was already addressed as 'tomb' (тúmßos).

85 Cornford $1961^{2}, 238 \mathrm{n}$. 12 compares the dismissal with the pharmakos rites at the Thargelia; Martin 1987, 90 with the 'cathartic apopompe of the Skira'.

86 See Baudy 1986. 
phalluses and cunni made of dough and brought up a 'baby'. The experimental boxes of earth and grain seed moistened with dew were laid down in underground caves around the Skira, i.e. at the summer solstice. Around one month later, in the last third of July, when Sirius rises, the seed boxes were brought up and exposed to the hot sun as a test of the seedlings' resistance. This practice was executed around the date of the Panathenaia. On the level of the oikos, each family deposited similar kistai, the gardens of Adonis, in dark cellars to bring them up about one month later onto the roofs at the Adonia. Thus, the state cult of the Arrhephoria gave the signal to perform the rite of the garden of Adonis in the oikos. ${ }^{87}$ In the coffins of Adonis, as in the Erichthonius boxes, was placed a phallus of dough, a sort of a dildo. That might be a comic reason why women notoriously look for dildoes to find pleasure in Lysistrata $(108,158,723)$. The phallus in the mystic box serves as a symbolic plough as well. Adonis, moreover, represents the young ephebe; on the roofs, the women and mothers violently lament his death which stands for the upcoming change of status for the youths. At the same time, seedlings in the Adonis garden quickly wither, as soon they are exposed to the sun of summer - symbolizing the sudden death of the beloved hero.

\section{Sex and the Maiden - or, from Chastity to Remarriage:}

A Symbolic Web of Allusions in Lysistrata

Once we have understood that the Lysistrata plays with the ritual complex of the rites around the Attic new year and the seed experiments, many details fall into place. In the parodos, the old women become notionally young girls, hudrophoroi, who fetch water at the EnneakrounosKallirhoe well. ${ }^{88}$ Its water also served for weddings; the women thus notionally return to nymphs and extinguish the fire with the water. They

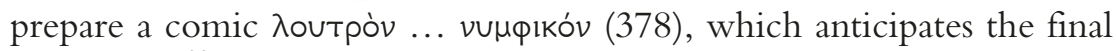
remarriage $;{ }^{89}$ the warm bath turns out to be urine (402). With other critics Burkert believes that the descent of the arrhepphoroi at their initia-

87 Baudy 1992, 38.

88 In terms of salvation, see Faraone 1997.

89 See also Dorati 1999. 
Baron Bluster! From women, I say, you get this kind of riotous extravagance!

Line 389 was the source for Lysistrata's alternative title Adōniazousai. ${ }^{92}$ Adonis is important because his rites are about the potted gardens of Adonis. The women are not riotous but simply perform their ritual duty - then as old women, now as notional maidens - to lament the dead ephebe, for the polis. ${ }^{93}$ Furthermore, the old proboulos himself is, to some extent, ephebized and threatened with being literally laid in the coffin (600). At the same time, a historical precedent is established: the Athenian women ritually cried out and mourned expressing their outrage about the fatal decision for the expedition to Sicily. The pun on the name Cholozyges (397) refers to Bouzyges. The Palladium, the wooden image of Athena - the goddess at the center of the whole play - was stored in a sanctuary near the Ilissus where Bouzyges was priest of Zeus. His curses were well known. The Bouzyges was responsible for a holy ploughing. Furthermore, there was a court at the Palladium and a procession of ephebes to cleanse the image, the socalled Plynteria, after they took the oxen from his yoke and ate it. The 'oxen-yoker' cursed them. The ploughing might allude to the context of the seed and is often associated with sexual activity. Violence and curses are connected - the politician was another old man who did not listen to the women. In the ambivalent comic speech, the curser is cursed as well; he is 'godforsaken', since he cares neither for the bad omen nor for the ritual action directed to the gods. Moreover, there might already be an allusion to the fact that the old men become notional ephebes who will marry at the holy ploughing time in autumn. The oxen, the old animal, has to die, like the proboulos. Furthermore, the magistrate is similar to the old curser, since his speech act in the following agōn is just such a curse. The positive solution of the conflict is anticipated, too, as the alleged violence and mischief will turn out as legal and righteous for the polis. ${ }^{94}$ The comic criticism of the women's sexual

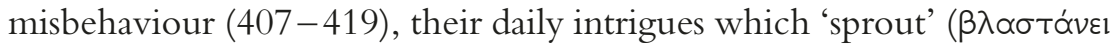
406), resembles the handling of the phallus/plough in the experimental

92 Scholium on Lys. 389, rejecting it. Reitzammer 2008 bases her entire Adonian interpretation upon this notice. On this passage Reitzammer 2008, 287-292, $318-324$.

93 For a more balanced view, against Detienne 1972 (Engl. 1994), see Reed 1995.

94 For the entire ritual background of Bouzyges, see Burkert $1970 \mathrm{~b}$. 
seed bed. Burkert says that gold jewelry had to be taken off, ${ }^{95}$ but the women are accused of doing obscene things with the goldsmith (408-413).

The contents of the kavã at the Panathenaia are also connected to the entire background of Lysistrata's texture. As mythical inventor of the kanephoric rite, Erichthonius is present at this central polis-festival as well. The sacrificial baskets are analogous to the arrhephoric kistai. Instead of the grain we have barley seeds and instead of the virtual snake and phallus we have a sacrificial knife with a deadly potential. In addition, the death of the hecatomb of cows corresponds to the symbolic death of the hundred maidens that march in the procession in initiation (Paus. 1.29.16). When female animals, i.e. the cows, are pelted with spermata, we may read this as a symbolic insemination, ${ }^{96}$ and the sacrificial death with the knife signifies defloration. The knife stands for the phallus (see Hesych.

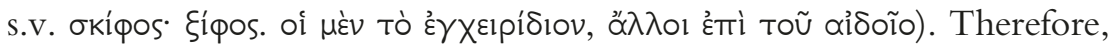
the women are more than suspicious when the men want to defend their democratic and male order, and cite, in a fragmented and reverse order

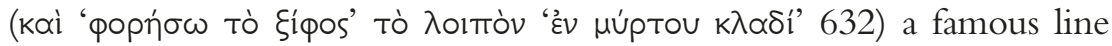

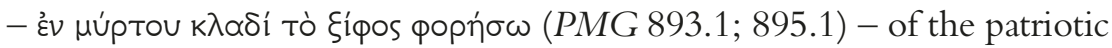
drinking songs (PMG 893-896) about the tyrant-slayers Harmodius and Aristogeiton. From the detailed description of Thucydides (6.54-58) we know to what extent the Panathenaia and love contributed to this famous deed. The homosexual couple is threatened by Hipparchus' sexual propositions to Harmodius, who refused. Aristogeiton, however, is jealous and plans an assassination. Because of the sexual rejection, Hipparchus takes revenge by humiliating Harmodius and his family. Peisistratus' sons focus on Harmodius' honour, typically choosing a cultic context: they select Harmodius' sister to be kanepphoros at the Panathenaic procession; when she comes, they chase her away, saying that she lacks dignity. Therefore, the couple now chooses the Panathenaia as the occasion for their attempt to kill the tyrants because men carried weapons for the sacrifice. However, due to complications they killed only Hipparchus with

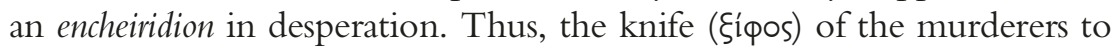
which the men refer is clearly linked to the Panathenaia and sacrifice, and has phallic associations. Furthermore, the erotic sense is emphasized by

95 Burkert 1966, $16(=1990,49)$.

96 See Baudy 1992, $42 \mathrm{f}$. 
the myrtle, which also stands for the female pubis. ${ }^{97}$ On the symbolic level the men threaten the women - finally returned to kanepphoroi at the end of their curriculum just before marriage - with sexual penetration, a sensation the kanepphoroi have to experience anyway. The same obscene association of छípos could also play a role in lines 148-156: Lysistrata explains her plan of a sex strike; when men see the women in their transparent gowns almost naked, men will get an erection and make

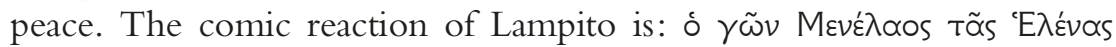

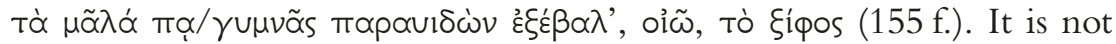
only an example of 'love triumphs over war', ${ }^{98}$ but it also has the sexual double entendre that Menelaos, having seen Helen's breast naked, 'threw out' ( $\varepsilon \xi \dot{\varepsilon} \beta \propto \lambda \varepsilon v)$ his erect phallus to 'fuck' her. As we all know, Helen is the ideal choragos of Alcman's partheneia, as mentioned in the final song (1296-1321, esp. 1314 f.). The Spartan lady would thus anticipate already the happy ending of remarriage after separation, with all its Laconian flair. ${ }^{99}$

When the plan has been impressively illustrated by Kinesias in a scenic play with Myrrhine (829-953, 954-979), the male Chorus comments on it with a wishful dream of rape (973-979): she should be whirled up into the air and land on his phallus. This fantasy recalls the aforementioned myth of Boreas and Oreithyia, the famous kanephoros and daughter of Erechtheus. After Kinesias, a Spartan counterpart appears on the stage (980-1013), a herald suffering with priapism (see esp. 985-996) or ithyphallic $\sigma \pi \alpha \sigma \mu o ́ s ~(845,1089)$. Thus, the sex strike is successful and results in hyperbolically erect phalluses on the part of the young excluded husbands. They also return, in a way, to the premarital status of ephebes bearing huge phalluses. This rite also plays a significant role in the festivals of the occasion, the Dionysia and Lenaia. Since this disease has become so terrible on both sides of the war that there are signs of surrender, the men send an envoy with full powers to both cities, Sparta and Athens, in order to make peace and, thereby, to finally be able to sleep with their wives again. At this point, a premature reconciliation emerges on the level of the Chorus (1014-1042). The old men, who in their rage

97 Lambin 1979. Myrtle is a symbol of Aphrodite and sexuality. See also Henderson 1987, 153 on Lys. $630 \mathrm{f}$.

98 Henderson 1987, 86 on Lys. 155 f. with other intertextual allusions.

99 Bierl 2007b (= Engl. [forthcoming]). As a Spartan, Lampito is already associated with feminine beauty (79 f., 83), sport, and choral dance movement (Totì $\left.\pi \cup \gamma \dot{\alpha} v \stackrel{\alpha}{\alpha} \lambda \lambda_{\circ} \mu \alpha 182\right)$ as soon as she is presented. On $\pi \eta \delta \dot{\alpha} \omega \omega$ and $\alpha^{\prime \prime} \lambda \lambda \circ \mu \alpha 1$ as choral terms, see Naerebout 1997, $281 \mathrm{f}$. 
have uncovered their torsos like the women (615, $663 \mathrm{f}$., $687 \mathrm{f}$.), are now wrapped up (1019-1042), and the women help to remove a giant gnat, a symbol of anger, from the eyes of the old men. ${ }^{100}$ There are kisses all around, and finally reconciliation is established between the half-Choruses that have hitherto directed their fury at each other.

In the end, the dangerous situation returns to normality, which implies a submission of the women to men. Only Lysistrata can heal and free the men from their sexual agony (1089). As a parodic double of Athena, she is largely exempt from the carnivalesque play regarding at least her own body. In her decisive act of reconciliation, she makes use of a typical naked female personification, namely of Diallage (1112-1188), and manipulates the former enemies with rhetorical means (cf. 1108-1111). ${ }^{101}$ Lysistrata mediates by reminding the Athenian and Spartan delegates of their common rituals and history. The Spartans and Athenians hardly listen to her wise words, but in their excessive, pent-up appetite they only have a look at the sexual parts of this female body; it will be distributed as territory to which both sides lay their claim. Quarrels about territory are comically projected upon the image of the attractive female body and settled according to ethnic preferences in sexual practices. The male physical desire is assimilated by metaphor and wordplay to the desire for land, which is the cause of the terrible war. Again we are confronted with a female body as a landscape in a mental mapping. The comic blend is based on etymological similarities between topographical and sexual areas, as we see, for example, in the following passage.

\begin{tabular}{|c|c|}
\hline ПРҮ. & 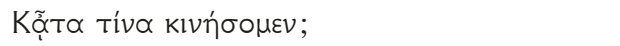 \\
\hline$\wedge Y$. & 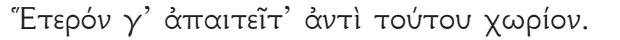 \\
\hline ПРҮ. & 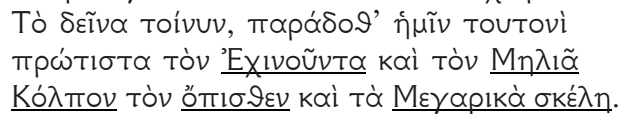 \\
\hline$\wedge \mathrm{A}$. & 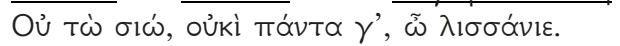 \\
\hline & 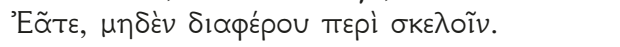 \\
\hline ПРҮ. & 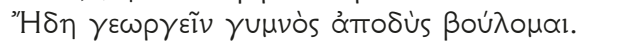 \\
\hline$\triangle A$ & 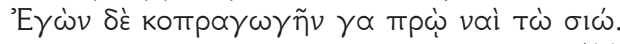 \\
\hline
\end{tabular}

$(1167-1174)$

100 This scene hints at sexual satisfaction.

101 See Stroup 2004, 62-68. 
FIRST Then who will we be able to harrass?

Athenian

Delegate

Lysistrata Just ask for some other place in return for that one.

First Well, let's see now. First of all give us Echinous here and the

Athenian Malian Gulf behind it and both Legs.

Delegate

Spartan By the Twain Gods, we're not handling over everything, dear

Delegate fellow!

Lysistrata Let it go: don't be squabbling about a pair of legs.

First Athe- Now I'm ready to strip down and start ploughing!

NIAN

Delegate

Spartan And bright and early I want to start spreading manure, by the Delegate Twain Gods!

Ploughing - the common agricultural metaphor for sexual intercourse alludes again to the context of seed. In the end, Lysistrata has settled the hostilities, and the peace agreement is sealed with a festive drinking party celebrated backstage. She invites the delegates and everybody to the Acropolis, whereas in ordinary circumstances, such dignitaries would be feasted in the Prytaneion. ${ }^{102}$ Lysistrata, in a pun, says they would host them on the Acropolis 'with what we have in our boxes

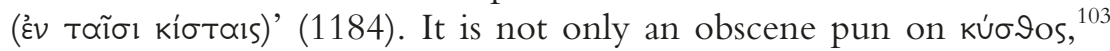
but with kírol she can allude to the famous boxes of the arrhēphoroi. Thus, the box is also a symbol in which ritual, the concrete experimental seed container, and the uterus converge - already highlighted in the mental mapping of the Acropolis. Now men and women come close to remarriage at the Panathenaia. In another interlude (1189-1215), the Chorus now offers to richly equip each boy and, above all, each girl that carries the basket at the Panathenaia as kanephoros (1194) - the girl we know from the famous line in the parabasis (cf. 646 f.); the audience too - here the Chorus now turns increasingly to the external level of the here and now - is invited to participate in the abundance of grain via a choinix, the measure of a man's daily allowance, that also suggests Athena in her function as the goddess of marriage. ${ }^{104}$

102 Henderson 1987, 206 ad Lys. 1184-1188.

103 Henderson 1987, 206 ad Lys. 1184-1188. Sommerstein 1990, 217 ad Lys. 1184 thinks of a 'handbox' which 'a Greek going out for meal' would take with him to a symposion.

104 Deubner 1932, 15 f. See esp. Arist. Oec. 1347a14-17. 
The Panathenaia and the rites of marriage associated with Athena then serve to conceptually situate the exit song (exodos), in which the success of the joint drinking party is celebrated with bands of revellers (kōmoi) characteristic of exodoi and symposia. On a choral and symbolic level, the hostilities are now ceased. First, by remembering the Spartan success in the Persian war, the performance creates not only cohesion among the Spartans themselves, but also common ground with their adversary in war, Athens - their former ally in the Panhellenic war against the Persians (1247-1272). Elsewhere, I have shown that all Spartan and Athenian men are notionally conceived as ephebes as well, and that the final reference to the partheneia of Alcman transfers the reunited couples to the state of remarriage. Spartan and Athenian cult and rituals are merged in Athena, the polis goddess of both cities and citadels. The reference to Alcman also conveys the atmosphere of the kosmos, the order in state affairs, in politics, in gender relations, and in the whole universe. ${ }^{105}$

\section{Conclusion}

Lysistrata consists of a complicated interplay of body, myth, ritual, and political crisis on the premises of metaphor and metonymy in a performative process. Thus, text comes together with context, with its sociocultural setting, and with the performance of such a script. In addition, the inherent social energy is acted out in pure fantasy and creative utopia; moreover, the body and the ritual are central media and 'distributional knots of energy' for all comedies. ${ }^{106}$ As I have shown, we can only understand this kind of play based on the body if we really take into account the grammar and function of the genre, as well as its mythic-ritual and iconic poetics. As far as women and the polis are concerned, the entire play oscillates between sexualized and desexualized bodies, Aphrodite/Adonis and Athena, hetaira/porne and holy virgin. Image merges with reality, private oikos with polis, and cultic space with body. All oppositions are encompassed in the comic ambiguity, and the shifts are performed by metaphoric predication constituted by myth, ritual, and mental mapping. Most of all, the plot is based on the comic leap of women into the state of maidens and Athenian premarital rites. Thus,

105 Bierl 2007b (= Engl. [forthcoming]).

106 Neumann 2000, 52. 
the women notionally return to girls and remarry their husbands at the end. All in all, the ritual and heortological program at the end of the Attic year is projected onto the play, fragmented, varied, and joined in performative terms. Moreover, the severe crisis is acted out on the comic stage and solved in a manner typical of the genre: peace, order, gender relations, and reproduction are finally restored. However, in real life the Athenians can only dream about overcoming the crisis in such a playful and easy way. Indeed, it is only Athena or her priest who can disband the army and battle with magic and peitho $\overline{\text {. Returning to }}$ normal life, the Peloponnesian War with all its consequences will continue, leading to its final catastrophe in 404 BCE. 